\title{
Some insights into nanotechnology innovation processes and patterns for advanced materials
}

\author{
Algunas percepciones de los procesos de innovación nanotecnológicos \\ y patrones para los materiales avanzados
}

\author{
Antonio Adrián Arciénaga Morales ${ }^{1 *}$, Janni Nielsen², \\ Eduardo Roveris Gomes ${ }^{3}$, Leif Bloch Rasmusen², \\ Hernán Bacarini ${ }^{4}$ and Britta Thomsen ${ }^{2}$ \\ Universidad Nacional de Salta, Argentina \\ ${ }^{2}$ Copenhagen Business School, Denmark \\ ${ }^{3}$ Serviço Nacional de Aprendizagem Industrial (SENAI), Brazil \\ ${ }^{4}$ Universidad Nacional de Luján, Argentina
}

Received November 30, 2017; accepted October 26, 2018

Available online November 9, 2018

\begin{abstract}
Nanotechnology innovation has peculiar characteristics. This paper reviews the methodology and results, drawn from cases analyzed on two EU projects: EULASUR and EULACERMAT. The cases covers both European and Latin American experiences, particularly from Mercosur countries. We analyze specifically nanotechnology innovation based on new and advanced materials. The main conclusion of this paper is that innovation in advanced materials, based on nanotechnology, relies crucially on networks of cooperative agents. It starts from the validated assumption that innovation is interactive in nature. Therefore, it is needed to co-create through the participation to obtain feasible results. The position of advanced materials within the related (new or existent) value chains explains to a great extend the border conditions for innovating in this nanotechnology field. It appeared clearly that innovation in this field is a complex problem, with the same degree as researching (nanoscience), and that the connections between them were not obvious nor simple.
\end{abstract}

\footnotetext{
* Corresponding author.

E-mail address: aarcienaga@gmail.com (A.A. Arciénaga Morales)

Peer Review under the responsibility of Universidad Nacional Autónoma de México.
} 
Concerning policy implications, it is useful to discriminate them in terms of the temporal horizon of what type of nanotechnology innovation should be promoted, particularly for developing countries' trajectories, for ensuring that the impacts of advanced materials will be suitable for the society.

JEL code: D85, L59, L61, O32.

Keywords: nanotechnology innovation; co-operative innovation; co-creation; advanced ceramics.

\section{Resumen}

La innovación nanotecnológica tiene características peculiares. Este artículo revisa la metodología y los resultados, extraídos de casos analizados en dos proyectos de la Unión Europea: EULASUR y EULACERMAT. Los casos cubren tanto la experiencia de la UE como de Latino América, en particular países del Mercosur. Analizamos especialmente la innovación nanotecnológica basada en materiales nuevos y avanzados. La principal conclusión de este trabajo es que la innovación en materiales avanzados se apoya crucialmente en redes de agentes cooperativos. Esto se apoya a su vez en el supuesto validado que la innovación es interactiva por naturaleza. Por ello, se requiere de un proceso de co-creación a través de la participación de diversos agentes para obtener resultados factibles. La posición de los materiales avanzados dentro de las respectivas cadenas de valor (nuevas o existentes) explica en gran medida las condiciones de borde para innovar en este campo de la nanotecnología. El proceso de innovación en este campo es un problema complejo, con los mismos grados de dificultad que el proceso de investigación (nanociencia), y las conexiones entre estos dos procesos no son ni obvias ni simples. Con respecto a las implicaciones políticas, es útil discriminarlas en un horizonte temporal en cuanto a qué tipo de innovación nanotecnológica debería ser promovida, en particular para las trayectorias de evolución de los países en desarrollo, para asegurar que los impactos de los materiales avanzados sean adecuados para la sociedad.

Código JEL: D85, L59, L61, O32.

Palabras clave: innovación nanotecnológica; innovación cooperativa; proceso de co-creación; cerámicas avanzadas.

\section{Introduction}

The assessment of the innovation process for Advanced Materials (AM) right now and in the near future is difficult to evaluate. However, there are some characteristics close related to patterns connected to the innovation process of this type of materials. For instance, they are at the beginning of many value chains. Therefore, they have the potential for applying to many sectors. Due to this generic effect, nanotechnologies are of great importance, for both developed and developing countries. This motivated our concern for this issue.

For analyzing the specific characteristics of nanomaterial innovation process, following we present some results and evidences picked up during two European Union (EU) Projects: EULASUR ("Network in Advanced Materials and Nanomaterials of industrial interest between Europe and Latin American Countries of MERCOSUR"), and EULANETCERMAT ("Ceramic Materials with Environmental and Industrial Applications").

The development of this paper is the following: in the next paragraph, we explain the methodology based on case studies; then, we review the literature and discuss some case studies from both regions. On this basis, we derive a model for innovation for nanotechnology, 
particularly related to advanced materials. Finally, in epigraph 5 we tried to drive some conclusions based on the previous topics, taking above all into considerations policy implication from this particular model of innovation.

\section{Methodology}

The contents and results of this paper are drawn from case studies, mainly in advanced materials. The cases were collected and researched by the authors in two regions: European Union and Mercosur countries. Comparisons from both regions add some richness to the analysis. Some other cases were taken from the literature, in the same or other regions, showing that the patterns synthetized matched very well.

The case study methodology consists on describing an interesting number of cases, covering different market sectors or segments. Then, we derived from them some stylized facts that cases showed in common. The concept of "Stylized Facts" is based on the methodological proposal of Kaldor (1965, p. 179) for social science. The idea is to characterize a complex surveyed subject posing the main points or facts, as a former approach. Then, these facts are grouped and then connected to introduce a dynamic focus on the subject. Finally, a model could usually appear after these steps. Besides, case-based studies rely on the concept of similarity, and more particularly on the idea that situations recognized as similar in important aspects may be also similar in other respects (Hüllermeier, 2007, p. 5). Thus, our approach is based on a simple instance of analogical or inductive reasoning that will end up with a generalization of an innovation model for nanotechnology-based advanced materials.

Case study is a theory-building rather than a theory-testing research (Eisenhardt and Graebner, 2007, p. 26). "Multiple cases are a powerful means to create theory because they permit replication and extension among individual cases. Replication simply means that individual cases can be used for independent corroboration of specific propositions. This corroboration helps researchers to perceive patterns more easily and to eliminate chance associations. Extension refers to the use of multiple cases to develop more elaborated theory. Different cases often emphasize complementary aspects of a phenomenon. By piecing together the individual patterns, the researcher can draw a more complete theoretical picture" (Eisenhardt, 1991, p. 620).

Recognizing patterns of relationships among constructs within and across cases is a crucial task for coming up with a theory. Case studies are different from lab experiment in the sense they emphasize the rich real-world context in which the phenomena occur. The theory-building is an emerging process that is based on recursive cycling and puzzling the case data, theoretical creation of constructs or models, posing propositions and/or midrange theory from cases, all of these based on the empirical evidence (Eisenhardt and Graebner, 2007, p. 26).

Besides, for capturing the interactions and relationships of all stakeholders present in each case, we use the value chain methodology (Kaplinsky and Morris, 2001). The relational character of this methodology allows capturing the range and type of interactions, relationships and possible innovative behavior within the value chain, both at micro-economic and mesoeconomic level. In some limited cases, most of them related to multinational subsidiaries, we used even the global value chain concept (Gereffi et al., 2005) to show the connections that the value chain exhibits with international stakeholders. We preferred the value chain tool instead 
of sectoral industrial classifications because the latter does not allow to research innovation process with sector-codes that are usually product-based rather than activity-based.

On value chain base, we synthetized all the data by constructing a graphic and logic model of nanotechnology-based innovation, trying to apprehend and deploy some specific patterns we found in the field and the nanotechnology cases, above all the regularity of the several applications of advanced materials. Finally, we derive some conclusions in terms of possible policies to apply for the development of nanotechnology innovation, particularly for less developed countries, taking into account different time horizons and different levels of development in this field. The Figure 1 reflects in a diagrammatic way the general methodology and rationale used for this research.

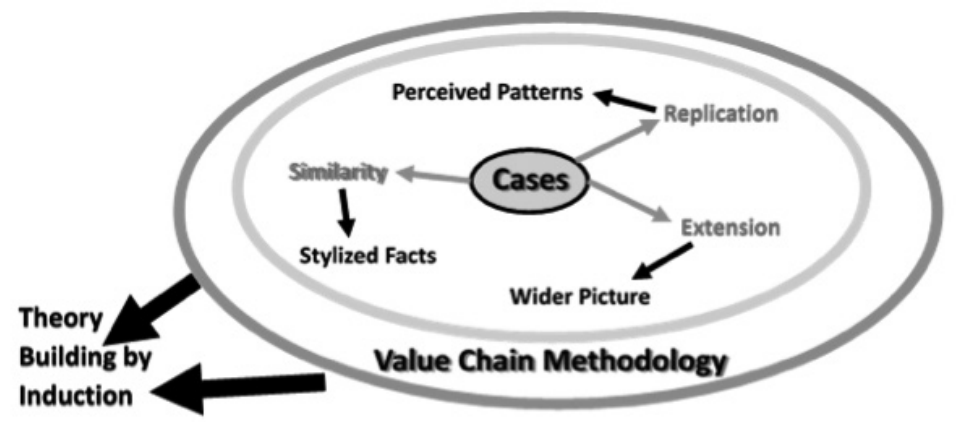

Figure 1: Methodology for Analysis.

Source: Own elaboration.

There were some studies that introduce the value chain analysis in the field of nanotechnology, particularly Lux Research (2006). The Figure 2 illustrates the links considered in this approach.

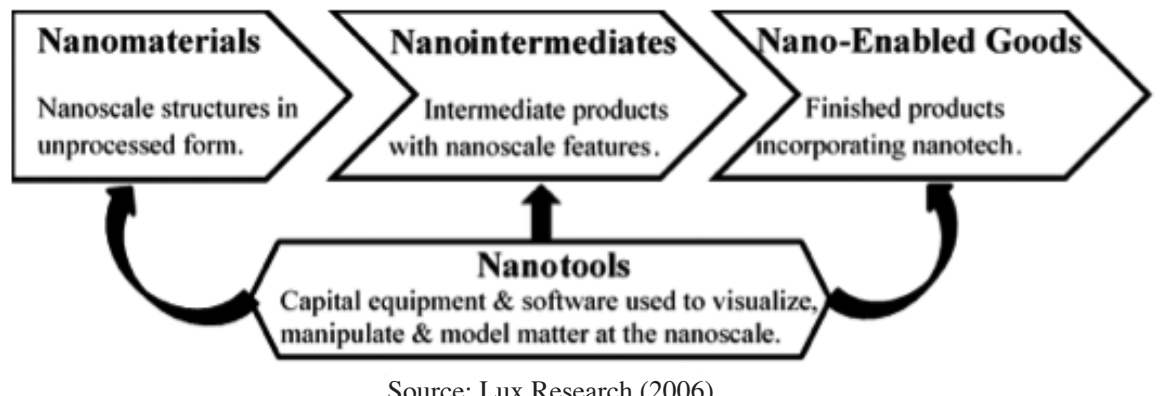

Source: Lux Research (2006).

These links highlight above all the technological transformations and relationships involved in nanotechnology innovations. There are other links we observed in the cases but were not considered in the cited work. They are of great importance in the case of Latin American countries, like public and/or private R\&D support, or public and private regulations, logistics links connected with other innovation patterns like servitization, or the role of final product 
markets (including nano-enabled goods with additional functions or characteristics) in pulling the value chain. We introduce and analyze them in epigraph 5.

\section{Literature review}

Next, we provide a literature review, focused on the patterns of innovation in the field of nanotechnology, with particular emphasis within nano-materials fields. The aim of the review is to add specific information, frameworks, and details of nanotech innovation processes to enrich the case analysis for capturing the very nature of the knowledge-based innovative process going on.

Nanotechnology-based advanced materials can be considered perfectly as generic technologies; i.e. those that may "yield benefits for a wide range of sectors of the economy and/ or society" (Keenan 2003,p. 130). The growth of research in the field of nanotechnology has far exceeded growth in science and technology research in general (Bozeman et al, 2007, p. 807). A whole panoply of applications are emerging from biomedicine to robotics, passing through quite different sectors. Sometimes, the potential for expectations exceed realities, crossing to the field of science fiction. However, in some sectors, like for instance nano-ceramics or textile nanomaterials, there has been real practical progress in applying nanotechnology. This potential of advanced material applications is in contrast with the difficulties of commercializing radical advanced materials technology, due to barriers that have been not well studied in the literature.

Over the last 50 years, advanced ceramics was continue evolving. The main front of this evolution came from and was impelled by pre-ceramic polymers, also called as polymerderived ceramics (PDCs), which were a fundamental material innovation that made possible the fabrication of mainly Silicon-based advanced ceramics. This technological breakthrough gave place to the development of many innovations in advanced ceramics, such as ceramic fibers, coatings, or ceramics stable at ultrahigh temperatures (up to $2000^{\circ} \mathrm{C}$ ), with significant properties for decomposition, crystallization, phase separation, and creep effect (see Colombo et al, 2010, p. 1805). The trend is to multiply material's properties, even designing them on specific demand (pret-a-porter), all of which makes stronger the impact of the material revolution nowadays.

Nanotechnologies are already present in many consumer products, including textiles. "Nanotextiles" can be considered as traditional textiles with the incorporation of nanoparticles. They present often functionalities such as antibacterial effects, ultraviolet radiation protection, water and dirt repellency, self-cleaning or flame retardancy. Nanoparticles can be released from the textile materials due to different effects (abrasion and other mechanical stresses, sweat, irradiation, washing, temperature changes, etc.). It is then expectable that "nanotextiles" may release individual nanoparticles, agglomerates of nanoparticles or small particles of textile with or without nanoparticles, depending on the type of integration of the nanoparticles in textiles (Sawhney et al., 2008; Stegmaier et al., 2007; Almeida and Ramos, 2017).

The most important exposure route of the human body to nanoparticles in case of textiles is skin contact. Several standards are being developed under the auspices of the European Committee for Standardization. In this last case, it has been presented the development and application of a test method to evaluate the skin exposure to nanoparticles, to evaluate the transfer of the nanoparticles from the textile to the skin by the effect of abrasion and sweat (Savolainen et al., 2013). 
As it can be observed in the cases mentioned above, the main strategy for innovation in this field, like in many nano-materials areas, is the application of new materials to "old" existent products, which diminishes the risks for innovation. The other alternative to this strategy is to manufacture new products with new materials, which involves greater risks and uncertainties. In the middle, there are also possible combinations of these apparently two excluding strategies.

On the other hand, from the specific innovation viewpoint, the know-how and the explicit knowledge required for innovating in advanced materials (AM) are distributed on a good number of R\&D centers, users, regulators, and firms. The producers of nano-materials do not necessarily know the application of them. Most of the time, they need access to specific knowledge for applications. Cooperative innovation comes up as the solution because it combines knowledge from different sources to produce process and product innovation within a collaborative network. Then, there is a process of co-creation of a product-service combination because of this cooperative network. Innovation result is very difficult to obtain by the narrow knowledge of individual agents (Nielsen et al, 2012; Faems et al., 2010). This innovation characteristic is also due to a great extent to the interdisciplinary nature of nanotechnology (Porter and Youtie, 2009), which means that for advancing on innovation it is necessary the participation of different experts for facilitating cross-disciplinary research and applications. Nanotechnology collaborations are also stimulated by geographical proximity (Cunningham and Werker, 2012) and the emerging innovation system in nanotechnology (Miyazaki and Islam, 2007), with varying involvement of academia, public research institutions, governmental participation and regulations, clusters or knowledge networks, value added chains, and commercial companies.

Other innovation strategy observed in the nano-material fields is the servitization process, i.e. "the innovation of an organization's capabilities and processes to better create mutual value through a shift from selling products to selling product-service systems"; that is to say integrated product and services that deliver value in use (Baines et al., 2009: 555). In the case of nanomaterials, manufacturers try to add value to innovative applications in new and old products (made with nano-materials) with knowledge intensive business services (Liu, 2015; Dinges et al., 2015). Even though servitization strategy does not represent a panacea for manufactures, however it allows firms to move up and strength the links within their value chain, making possible in this way to obtain higher value than simply commercializing new materials (Parry and Tasker, 2014; Cavalieri and Pezzotta, 2012) or applying them to known products.

\section{Development: cases and model}

Next, some of the innovation cases analyzed in this paper will be described to highlight common patterns of behavior and identify barrier to innovate. The cases for this work are essentially those reviewed in Europe and Latin America within two EU projects: EULASUR and EULACERMAT. In the following paragraphs, we describe and synthesize the different cases under analysis. The descriptions try to highlight stylized facts and patterns that arise from these sources of information.

While these summaries cannot do justice to the richness of each case, they show at least the significant effort involved for the firms and the edges or facets of interest. The main patterns studied in each case are the general framework of the innovative experience, description of the innovation itself, origin of the knowledge for the production and applications of the new 
material, position of the stakeholders in the value chain, products generated (whether they new or existent), and the results obtained. Next, the most indicative case are presented for space limitations.

Concerning new entrants and incumbents firms, the prominence of different actors will be outlined, but we can advance that they vary with the sector, and the type of applications involved. There were twenty cases surveyed in Latin American countries (mainly, Argentina and Brazil) , and the same amount for the European Union . In both cases, the reports were performed for EULACERMAT Project. Next, we describe some cases for many different applications that are valuable in sectors like health, energy, textile, environment, and electronics. Most of the time, the nanotech products can be applied for more than one sector or application because they involve generic technologies.

In the first case, for advanced materials (AM) applied to the health sector, the especial components or products for medical, dentist or other professional utilization show that there are several aspects to be taken into account for innovate. Some are related to the production itself and others related to the way of application, to customer's knowledge for profiting from them, and to health regulations. Innovators took these different fronts together for being successful, as it was reported for advanced materials application case in health sector in Brazil.

Some other AMs health products have different behaviors in customer's interactions, but they are most of the time at a "far distance" of the final customers. Such distinct behaviors can be observed in some cases, where the same nano-material is applied in different ways. For instance, in Brazil, an anti-microbial material applied on products for medical usages and handled just by highly qualified personal, did not reach the final regular customers (the patients). However, the same material can pass through the different actors of the entire value chain and reach the final customer, when it is applied to manufacture toothbrush or toys as a preventive for contamination. For that purpose, the firms had access to the know-how of the particular regulations, production, and marketing of these last products.

Another interesting case is the application of advanced materials to the solution of environmental problems in Europe. Applications come mainly from the nano-ceramics (see Eaton, 2015), which are defined as "ceramic materials comprised of particles of a certain size, usually 100 nanometers diameter or less" (see http://nanoceramics.co.uk/). Nano-ceramics can be manufactured to have different properties than conventional ceramics, for example, their superior qualities for conduction or insulation that can facilitate new applications in electronics. Besides, their qualities have uses in physics, chemistry, engineering and materials, medicine, biology, agriculture and computer science (Meyer \& Persson, 1998; Mehta, 2002). However, it is to environmental applications, such as the treatment of drinking water or the filtration of contaminants from hot gasses, that the physical and chemical properties have most successfully been applied and commercialized to date, which can also be applied to Latin America (Castañeda Olvera et al., 2017).

Other cases in the environmental field use some nano-encapsulated materials for attracting weighted metals, like cobalt, chrome, etc. This product, developed in Brazil, let to perform a cleaning process in a landfill contaminated with these metals. Again, many actors are involved in this case: the product needs particularly a regulation approval, which includes some knowledge for field application, the participation even of the society in the perception of the environmental improvements, knowledge of the processes involved in the landfill, among all. 
There are some other cases on the nano-encapsulated materials field in Brazil, where the capsule material was originally developed for the cosmetic industry with the objective to prevent the active principles to oxidize. Then, it starts to be interesting to the chemical industry, where it was applied as an additional process control to the chemical reaction. In this last case, the capsule just breaks in the right time to produce a high quality reaction, which in turn promotes an important increase on the material properties leading to an improved product. The nano-producer has different opportunities in different sectors, involving a wide range of specific knowledge to produce innovations.

In Argentina, a medium domestic firm produces -in partnership with an US firm- an encapsulated nanomaterial, which can be called as a platform. This nano-particle has the capacity to encapsulate cytotoxic, antibiotic, radio isotopic, and a great variety of active molecules. Besides, they are also working on functionalizing the surface of this molecule to guide it to specific places or organs. This last property is of great value in different fields like medicine, chemical diagnosis, and food sector. The firm is located upstream in the pharmaceutical value chain, with no products for final consumers, and it is an incumbent that has incorporated nanotechnology research and manufactures intermediate products. The firm has research activities from their beginning in the 1990s, which was a natural platform for incorporating nanotechnology developments in their products.

There is another young technology based firm, located in the SAPEM Technology Park in Santa Fe (Argentina), which works on nano-bio solutions on demand. They develop liposomal products, from customer's idea to the scaling up of the solutions. Liposomes are phospho-lipid vesicles that can be excellent vehicles of useful molecules (drug delivery), with important properties in their interactions with cell membranes. This particular form of encapsulating drugs is applied to pharmaceuticals, cosmetics, and nutraceutics with increase functions like bioavailability, reduction of toxicity, and increase efficiency allowing dose reduction. This spin-off defines itself as a network with the academia, where they base their capacity to obtain or validate knowledge to solve problems, and for offering in this way a knowledge intensive service to customers.

Another interesting case is starred in by a new argentine nanotech firm, which can be considered as a spin-off of the National University of Litoral. The firm produces a wide variety of nanomaterials, including an anti-bacterial material based on nano-silver compounds. This is sold to a paint manufacturer, who incorporates it in acrylic paints giving them asepsis function, with suitable uses in places like hospitals and food industries. The paint manufacturer contributed with his know-how about paint manufacturing, commercialization channels, post-sell services, and regulations. In this sense, the alliance with the nanotech firm was fundamental for complying with American (ASTM D-3273) and Japanese (JIS Z 2801-2000) standards. The paint asepsis property lasts all along the product cycle, eliminating $99.999 \%$ of pathogen bacteria. This nano-silver particles are also sold to the textile industry, for producing a comfortable insole, which eliminates odors by eliminating the bacteria within the shoes. They also apply this nano-silver compound for the production of sanitary bandages, with an antibacterial center that liberates silver ions. This last product was approved by the national authority that regulates the health industry (ANMAT).

These cases show that even though the developed AMs are already on the market and adjusted to some specific applications, the different actors (of the different value chains) can 
change the focus when a new application is developed or come up. In this particular case, not just the final clients of the technology change but also the regulatory agency, the logistic channels, the incorporation of servitization as a new front of innovations with new stakeholders, the alliances or partnerships, and sometimes even the producer facility must be adjusted to meet these new market criteria and regulations.

It is interesting to note that similar characteristics showed the case of innovation with carbon nanotubes in U.S.A. The pioneer firm involved, Hyperion Catalysis Inc., developed first the raw material and after patenting products and processes, it focused on the search for a partner in different established sector to get the know-how of concrete products. Therefore, the main strategy for innovate was a collaborative scheme with partners already operating in different value chains. The firm also carried out by its own some projects in emerging field, like astronautics. In the former case, Hyperion was quite more successful than in the latter (cfr., Maine and Garnsey, 2005, pp. 18-22; Arciénaga and Bacarini, 2011).

Another interesting case is a public firm in Argentina that has developed infrared sensors for satellites produced in Argentina. The scientific background of the firm was close connected with the development made by the academia. On the other hand, the public purchase power behind the decision of launching a national satellite and the close relation of the firm with the national authority were a key trigger to cluster the academia, the developer of the sensor, and the national satellite contractor firm.

In the energy field, there are several examples. An interesting one is a spin-off incubated in the FAN (Argentine Foundation for Nanotechnology), that produces on demand ultra-thin, flexible, and custom shape lithium battery. The IoT (Internet of Things), applied to wearables and medical devices, requires new formats, minimum volume, and comfortable use. Ultrathin devices, based on nano Li-Ion battery, are capable of solve this need. They produce such devices by means of additive manufacturing technologies, using a 3D printer. Previously, a customized engineering is carried out with the client -in an intensive knowledge interactionfor designing the battery.

For summing up these cases, we can point out different facts: the prominence of the actors, of the regulation, of the upstream position or distance of advanced material innovation to the final customers. Besides, the role of logistics and interactions could varied, but there seems that all these co-creating relationships are particularly important for the introduction of innovations within the advanced material sector and for assessing the impacts of such products on markets and society. Like Maine and Garnsey (2005, p. 4) put it: "An innovation creates value for consumers when the products it enables outperform existing substitutes, match substitute performance at lower cost, or meet consumer needs for which there is no existing substitute. Value capture measures the extent to which the originators of an innovation are able to appropriate this newly created value."

\section{Results: stylized facts for modelling}

The particular upstream position of advanced materials (AM) in the value chain of many applying sectors brings some consequences, which could explain future introduction of new products based on these new materials. The following are the main stylized facts or the regularities derived from cases and literature review, which constitute a kind of innovation pattern for nanotechnology based new materials: 
- The industry that produces raw materials and components based on new advanced materials is usually at the beginning links or upstream of different value chains, usually restricted as providers.

- These links are far from final customer, which can constitute a new limitation for the rate of introduction of these type of materials.

- The "distance" from the suppliers and producers to the customer can vary according different sectors. This distance expressed the level of shared information, confidence, interactions and cooperative behavior. A long distance means a lower level of this variables or necessary conditions for innovating.

- Such distance affects the flow of information between final customers and first suppliers, particularly in terms of requirement and specifications, but it can also influence on both suppliers' behaviors, on their economic and technological stimuli for determining the strategy to innovate, and on the lack of trial spaces for the product.

- A long distance can be considered an internal barrier or a constraint within the value chain for possible new applications of advanced materials.

- Some of the links among suppliers and producers (of different kind), located in the middle of the value chain, can also acts as bottleneck or constraints for the introduction of innovative materials within a value chain because they can be affected in their established interests or investments by new advanced materials.

- Therefore, there are additional problems to innovate with advanced materials than with other type of products. Sunk costs of invested capital, commercial contracts, product stocks, economic power, and strategic decisions are some of the constraints that incumbents along the advanced material value chain face to innovate.

- For suppliers, there exists a high specific knowledge in AM design and production, and a low knowledge in the applications. The knowledge for innovate is distributed along the provider-producer-user chain.

- Nanotechnology innovators have two type of uncertainties: one about product value for consumer (translated into product attributes) and second about foreseen costs in the innovation production. Both involve investments on innovation information and a pilot plant, before viability is confirmed (cfr. also Maine and Garnsey, 2005).

- Most of the time, nanotechnology-based advanced material innovations required downstream complementary innovations or changes, which in turn increased downstream barriers or resistances to innovation adoption upstream.

- For overcoming all these problems, particularly the latter, innovation in advanced materials, based on nanotechnology, relies crucially on networks of cooperative agents (cfr. Nielsen et al, 2012). 
- Solutions required -as a necessary condition- a process of co-creation by means of the participation of suppliers and producers, and even advanced final customers, to obtain feasible results. The important positive role of advanced customers for the innovation process was well proved by Erick von Hippel in many publications (cfr. von Hippel (1988) and Thompke and von Hippel (2002)). Collaboration and co-creation imply to deal with a new type of customer along the value chain. Old customers are passive consumers of value instead of active collaborators and co-producers of value. They emphasize transaction-based relationships instead of interactions and experience-based relationships. They prefer to be a fixed and invisible link at one point of a long value chain instead of being an adaptive and very visible link, anytime, and anywhere. Finally, in old customers the concept of value is related to what companies offer (one size fits all) and not to the criteria that customer determines and tailors a unique solutions and a customized experience (cfr. Bhalla, 2011, pp. 4-5). The cooperation or collaboration could be extended even to rival firms (von Hippel, 1987).

- In most of the cases, innovation aroused when the chain links that play the role of customers were better educated, more collaborative, and more resourceful for their supplier, than in traditional value chain. This implies an information and interlocked customers-suppliers relationships that were quite profound in terms of value creation and innovation agenda for the value chain under consideration.

- These findings of different forms of cooperation confirm the old assumption that innovation is interactive in nature (cfr. Lundvall, 1992).

- Therefore, nanotechnology innovation can be modeled in first place as an interactive and above all cooperative innovation process (cfr. Nielsen et al, 2012; Porter and Youtie, 2009).

- Innovation based on nanotechnology-advanced materials can be deployed by two typical general strategies: first, by producing new products with new materials, with high uncertainty, and second by producing old products with new materials (with lower risk).

- With regard to the influence of nanotechnology $R \& D$, the interdisciplinary and transdisciplinary character of the research activities in this field (cfr. Meyer \& Persson, 1998; Gibbons et al, 1994) is translated to a large extent into the innovation process.

- There are also regulations, closed to customers and closed to the environment, that also can stimulate or inhibit the introduction of this type of products. Regulations for environmental impact assessment are far more developed in Europe than in Latin America, even though there appeared in the last 10 years some important decisions in national government agendas at Mercosur. These regulations are crucial for the development of nanotechnology innovations in any region. Risk analysis and regulations are still an open agenda, even in Europe (see Savolainen et al, 2013, pp. 25-26). 
- Regulations and a deeper understanding of nanotechnology impacts, in a particular environmental field or a socio-economic area, usually led to significant time lags for the development of novel innovations in this field (Owen and Goldberg, 2010). There is an increasing concern for the risks in the utilization of nanotechnology materials that includes not only the regulators, but also consumers and the industries (Savolainen et al, 2013 , p. 88). Environmental impact is fundamentally assessed on the basis of in vivo/ in vitro toxicological studies and surveying of physical/chemical properties of nanomaterials released into the environment. Besides, other risk analysis include also the integration of safe-by-design, closed production-to-product, and green nanotechnology approaches into the development stages of new nanomaterials and their applications (Savolainen et al, 2013, p. 24).

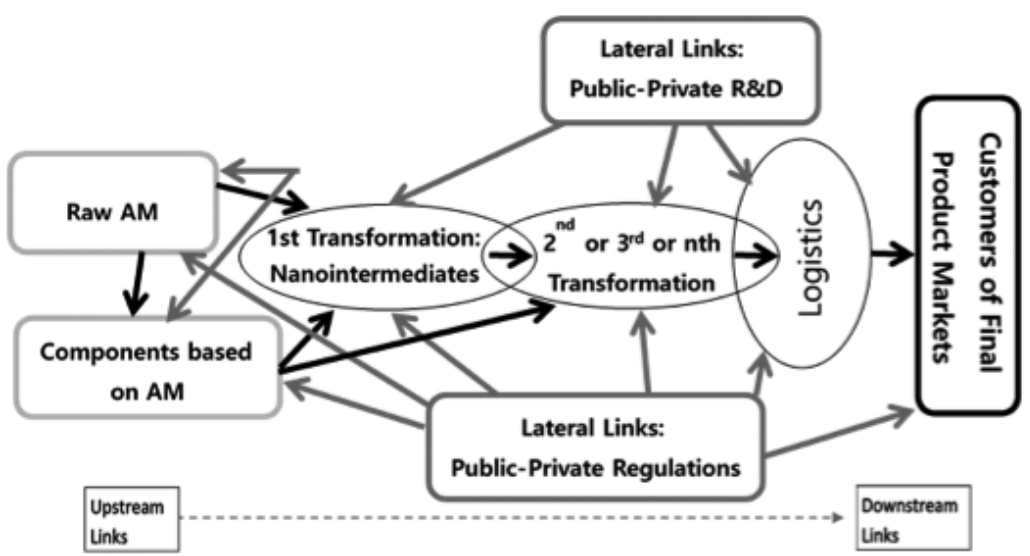

Figure 3: Dynamics of Innovation on Nanotechnology Materials. Source: own elaboration

- Therefore, responsible innovation is almost a sine qua none condition for nanotechnology innovation. Many unintended consequences of human actions, particularly related to global climate change, are modifying the behavior of governments, firms and society because their effects may be so profound that the very future of human society is under serious risks. Nanotechnology innovation is not an exception in this forced evolution. Responsibility seems to be the answer to this survival requirement, to avoid catastrophic consequences. Therefore, the need to innovate is entering in a new phase: to innovate responsibly (cfr. Owen et al, 2009, p. 6902). It is worth to mention that the cases surveyed have in common a responsible preoccupation of the firms for regulations, particularly those related to environment. However, in the final markets many products do not declare explicitly the content of nano-compounds, perhaps to avoid final customers' rejection, lack of acceptance or to circumvent in some cases the tendency to prefer natural products. 
- Particularly in Latin American cases, but also in many European ones, governmental support for research and innovation is crucial in nanotechnology. Nanotechnology activities and innovations are a significant output of commercial companies in Japan and USA. In contrast, in Europe, academia and government research institutions dominate the relevant scientific activities (Miyazaki and Islam, 2007). Most of the time, the knowledge is researched in a public R\&D center, and there exists several spin-off or incumbent firms that take advantage from this public investment in nanotechnology. These supports interact with all the links or firms along the value chain. Therefore, public and private $R \& D$ centers are a kind of lateral link interacting with all the central links.

The above diagram (Figure 3) synthetize the model on which we had applied largely the above ideas and facts, presented by the considered cases. The innovation process is in the graphical model extended in both directions of the supply chain (upstream and downstream). The model combines process and product innovation within a cooperative or collaborative network. Then, the management of suppliers, producers, and users relationships are fundamental for characterize nanotechnology innovation process. Neither suppliers or producers nor users can independently create this collaborative network using its own resources. This network is a key part in the innovation process to meet market requirements or performance for product and/ or service at a competitive cost. Besides, the model highlights that advanced materials are at the beginning of many value chains (health, energy, environment, car industry, building industry, etc.). The distinction between raw materials and component based on AM is in some way arbitrary because the same raw nanotech material can be a component in a different position according the specific value chain, as we can observe in the cases.

The introduction and acceptance of products based on AM (advanced materials) depend on the different solutions and trajectories that can be adopted for this pattern of nanotechnology innovation. New material applications for existing products are required to outperform existing substitutes, or match them at lower cost; in case of new product with new materials they are required to meet consumer needs for which there is no existing substitute (Maine and Garnsey, 2005).

Besides, the value chain model of Figure 3 tries to capture new forms of innovation like servitization. This process relies heavily on logistics to provide value added service to customers. Some of the studied cases define themselves as service firms, but they really capture the customers' needs and transform them into products plus services. For this purpose, the Figure 3 highlights the logistics connections with customers.

Most of the time, nanotechnology firms are trying to shorten the "distance" with their customers, particularly those for final products that include enabled nanotech products. This task is regularly performed because the main crucial form to capture clients' value is mixing nanotechnology knowledge with specific application's knowledge. Next, we try to drive some conclusions based on the previous topics. 


\section{Conclusions}

The reviewing of the cases throws as a main result the interactive and cooperative model, reflected in Figure 3. It synthetizes the main characteristics of the innovation process in the nanotechnology field. Therefore, based on this model, one of the main conclusions of this paper is that innovation process in advanced materials, based on nanotechnology, relies crucially on networks of cooperative agents. The rationale of the model starts from the validated assumption that innovation is interactive in nature, but it is also due to the nature of nanotechnology interdisciplinarity (Meyer \& Persson, 1998) and even transdisciplinarity (Novotnik, 2001), and the particular position of advanced materials in the respective value chains. Furthermore, the networks should ensure the participation of different stakeholders and not be confined to academic researcher, like it happened in Argentina, because this makes innovation and investigation do not function in parallel and in close relationship (Vila Seoane, 2011, p. 111), reducing inter and trasdisciplinarity.

Therefore, it is required to co-create within the innovation process through the participation of different stakeholders to obtain feasible results. The model here suggested needs further validation through empirical data analysis in appropriate network settings. On this basis, the paper offers a network viewpoint to be considered by innovation management, particularly the requirements for public-private partnerships because of the importance of public R\&D centers and public regulations in both regions.

However, we can also derive some other results by discussing quite different policies implications from this particular model of innovation, complementing the analysis at mesoeconomic level. In first place, the model seems also able to address the impacts of nano and advanced ceramics on the markets and the society. In this case, it is useful to discriminate them in terms of the temporal horizon of nanotechnology innovation to be carried out, for ensuring that the impacts of AM will be suitable for the society.

The following diagram (Figure 4) describes the different policies and measures that are needed from a time perspective. The first type of nanotechnology innovation affects society and markets in the short term. The outcomes of this measure are particularly focused on generating awareness and demonstration effects about this new technology and its applications. It is particularly important when we talk about new products with new materials, given the higher risks and uncertainties involved. The other option is to develop old products with AM. This latter type of innovation is an interesting platform for less developed countries to start with nanotechnology-based innovation process, because they involves lower risks.

In the second cases, the foreseen impacts of nanotechnology are on the structural problems of the society, like energy, environment and health solutions (in a 5 to 10 years horizon). It is necessary a much longer time to produce the desired effects based on these new materials for today and future solutions. In parallel, the regulation acts as a support to develop the solutions for structural problems, minimizing or eliminating non-desired collateral impacts. In this sense, the regulation related to the assessment of nanotechnology impact is of utmost importance. In this long term, the significant time lags for the development of novel innovations due to regulations in this field is not a constraint for solving structural problems.

Finally, there are impacts in the very long term (in a 20 years horizon) that are more difficult to forecast. For sure, if the new technology (like nano-materials) pretends to be sustainable, it will need to address new bottlenecks and problems of future society. Therefore, this new knowledge base probably will solve new problems yet not known. 
Synthetizing, it appeared clearly that innovation in this field is a complex problem, with the same degree of complexity like researching (nanoscience), and that the connections between nanotech innovation and nanoscience are not obvious nor simple. The pattern of advanced material innovation is a contribution to deepen into this complex phenomenon. Concerning policy implications, the discrimination of the temporal horizon in close relationship with the type of nanotechnology innovation that should be promoted, can contribute to identify suitable strategies for developing countries' trajectories, and for ensuring that the impacts of advanced materials will be translated into quality of life for citizens in the society.

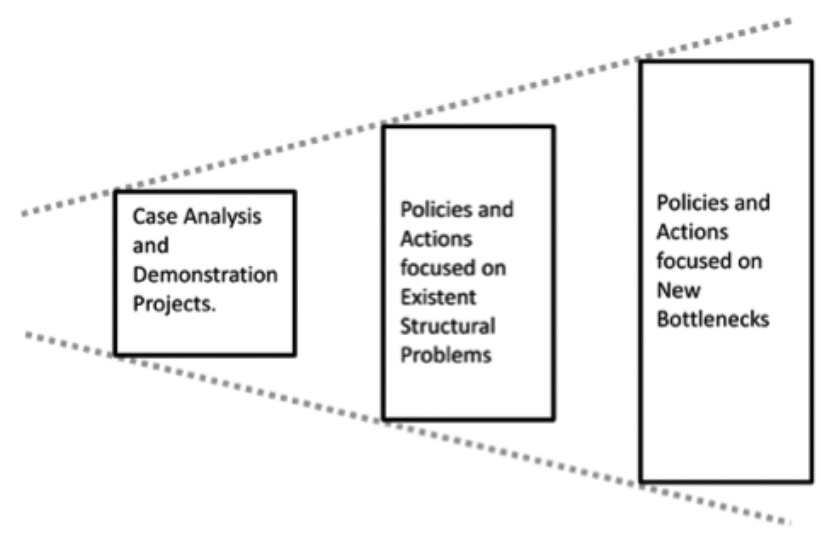

Figure 4: Temporal Horizon for Nanotechnology Innovation Impacts. Source: Own elaboration.

\section{References}

Almeida, L., and Ramos, D. (2017). Health and safety concerns of textiles with nanomaterials. 17th World Textile Conference AUTEX 2017- Textiles - Shaping the Future. IOP Conf. Series: Materials Science and Engineering, Vol. 254. https://doi.org/10.1088/1757-899X/254/10/102002.

Arciénaga, A., and Bacarini, H. (2011). Case Study in Materials Innovation: Hyperion Catalysis Inc. and the Carbon Nanotubes. EULASUR Workshop "From Materials to Products", promoted by the European Union and Mercosur, April 7 to 9 of 2011, in Belo Horizonte (Brazil). Available in https://projects.icmab.es/eulasur/events. Date of access: 15/08/2014.

Baines, T.S., Lightfoot, H.W., Benedettini, O. and Kay, J.M. (2009). The Servitization of Manufacturing: A Review of Literature and Reflection on Future Challenges. Journal of Manufacturing Technology Management, 20 (5) 547567. https://doi.org/10.1108/17410380910960984.

Bhalla, G. (2011). Collaboration and Co-creation. New Platforms for Marketing and Innovation. Reston (VA - USA): Springer Science+Business Media, LLC. https://doi.org/10.1007/978-1-4419-7082-4.

Bozeman. B., Laredo, P., and Mangematin, V. (2007). Understanding the Emergence and Deployment of "nano" S\&T. Research Policy, 36, 807-812. https://doi.org/10.1016/j.respol.2007.02.010.

Castañeda Olvera, Rafael; León Silva, Sein; Robles-Belmont, Eduardo and Záyago Lau, Edgar (2017). Review of nanotechnology value chain for water treatment applications in Mexico. Resource-Efficient Technologies. 3 (1), 1-11 https://doi.org/10.1016/j.reffit.2017.01.008.

Cavalieri, Sergio and Pezzotta, Giuditta (2012). Product-Service Systems Engineering: State of the art and research challenges. Computers in Industry, 63, 278-288. https://doi.org/10.1016/j.compind.2012.02.006. 
Colombo, P., Mera, G., Riedel, R. and Soraru, G. D. (2010). Polymer-Derived Ceramics: 40 Years of Research and Innovation in Advanced Ceramics. Journal of American Ceramic Society, 93 (7), 1805-1837. https://doi. org/10.1002/9783527631971.ch07.

Cunningham, Scott W., and Werker, Claudia (2012). Proximity and Collaboration in European Nanotechnology. Papers in Regional Science, 91(4), 723-742. https://doi.org/10.1111/j.1435-5957.2012.00416.x.

Dinges, Veit; Urmetzer, Florian; Martínez, Verónica; Zaki, Mohamed and Neely, Andy (2015). "The Future of Servitization: Technologies that will make a difference." Cambridge, UK: Cambridge Service Alliance, University of Cambridge. Available in https://cambridgeservicealliance.eng.cam.ac.uk/resources/Downloads/Monthly\%20 Papers/150623FutureTechnologiesinServitization.pdf. Date of access: 13/06/2018.

Eaton, Ben (2015). "Mapping the environmental ceramics industry in the EU/EAA". EULACERMAT-Marie Curie Report. Copenhagen: CBS.

Eisenhard, Kathleen M. (1991). Better Stories and Better Constructs: the Case for Rigor and Comparative Logic. Academy of Management Review, 16 (3), 620-627. https://doi.org/10.5465/AMR.1991.4279496.

Eisenhardt, Kathleen M., and Graebner, Melissa E. (2007). Theory Building from Cases: Opportunities and Challenges. Academy of Management Journal, 50 (1), 25-32. https://doi.org/10.5465/AMJ.2007.24160888.

Faems, Dries; Janssens, Maddy and Van Looy, Bart (2010). Managing the Co-operation-Competition Dilemma in R\&D Alliances: A Multiple Case Study in the Advanced Materials Industry. Creativity and Innovation Management, 19 (1), 3-22. https://doi.org/10.1111/j.1467-8691.2010.00546.x

FAN (2015). Fundación Argentina de Nanotecnología. Catálogo de Empresas. Available in: http://www.fan.org.ar/ acciones/cde. Access on December 2017.

Gereffi, G., Humphrey, J. and Sturgeon, T. (2005). The governance of global value chains. Journal Review of International Political Economy, 12 (1), 78-104. https://doi.org/10.1080/09692290500049805.

Gibbons, M.; Limoges, C.; Nowotny, H.; Schwartzman, S.; Scott, P., and Trow, M. (1994). The New Production of Knowledge. The Dynamics of Science and Research in Contemporary Societies. London: Sage Publications Ltd. ISBN-13: 978-0803977945.

Hüllermeier, E. (2007). Case Based Approximate Reasoning. Dordrecht, The Netherlands: Springer. https://doi. org/10.1007/1-4020-5695-8.

Kaldor, N. (1965). Capital Accumulation and Economic Growth. Included in Lutz, F. y Hague, D. (Eds., 1965). The Theory of Capital. London: International Economic Association \& Macmillan, pp. 177-222. ISBN-13: 9780333406366.

Kaplinsky, R. and Morris, M. (2001). A Handbook for Value Chain Research. IDRC. Available in https://www.ids. ac.uk/ids/global/pdfs/VchNov01.pdf Access date 15/02/2015.

Keenan, M. (2003). Identifying Emerging Generic Technologies at the National Level: The UK Experience. Journal of Forecasting, 22 (2/3), 129-149. https://doi.org/10.1002/for.849.

Liu, Meng-Chun (2015). Manufacturing servitization and revitalizing industrial clusters: a case study of Taiwan's LIIEP. Journal of the Asia Pacific Economy, 20 (3), 423-443. https://doi.org/13547860.2015.1054168.

Lundvall, B (1992). National Innovation Systems: Towards a Theory of Innovation and Interactive Learning. London: Pinter. ISBN: 1-85567-063-1.

Lux Research (2006). Nanotechnology Commercialization - Industry and Environmental Impacts. Workshop on Nanotechnology Lifecycle Assessment - October 2-3, 2006. Available in: http://nanotechproject.org/file_download/files/ Holman-LUX-LCA.pdf Access june 13 of 2018.

Maine, E. and Garnsey, E. (2005). Commercializing Generic Technology: The case of Advanced Materials Ventures. Cambridge Document $N^{\circ}$ 2004/04. Cambridge: Institute for Manufacturing, University of Cambridge.

Mehta, Michael (2002). Nanoscience and Nanotechnology: Assessing the Nature of Innovation in these Fields. Bulletin of Science, Technology \& Society, 22 (4), 269-273. https://doi.org/10.1177/027046760202200402.

Meyer and Persson (1998). Nanotechnology-Interdisciplinarity, Patterns of Collaboration and Differences in Application. Scientometrics, 42 (2), 195-205. https://doi.org/10.1007/BF02458355.

MINCYT (2009). Boletín de Estadística Tecnológica - Nanotecnología en Argentina. En http://www.mincyt.gob.ar/indicadores/boletin-estadistico-tecnologico-bet-nanotecnologia-8023 Access date 18/05/2015. Ministerio de Ciencia, Tecnología e Innovación Productiva 
Miyazaki, K. and Islam, N. (2007). Nanotechnology System of Innovation - An Analysis of Industry and Academia Research Activities. Technovation, 27 (11), 661-675. https://doi.org/10.1016/j.technovation.2007.05.009.

Nielsen, Janni; Rassmussen, Leif; Yaganeh, Suzanne; Bacarini, Hernán and Arciénaga, Antonio (2012). Cooperative Innovation Landscapes - Visualising Empirical Findings from an Euro-Latin American Project. Participatory Innovation Conference 2012, Melbourne, Australia.

Nowotny, H. (2001). The Potential of Transdisciplinarity. Included in J. Thompson Klein, W. Grossenbacher-Mansuy, R. Häberli, A. Bill, R. W. Scholz, M. Welti (Hg.). Transdisciplinarity: Joint Problem Solving among Science, Technology, and Society. An Effective Way for Managing Complexity. Berlin: Birkhäuser Verlag, Pp. 67-80. https://doi. org/10.1007/978-3-0348-8419-8_7.

Owen, R., Baxter, D., Maynard, T., and Depledge, M. (2009): Beyond Regulation: Risk Pricing and Responsible Innovation. Environmental Science Technology, 43, 6902-6906. https://doi.org/10.1021/es803332u.

Owen, Richard, and Goldberg, Nicola (2010). Responsible Innovation: A Pilot Study with the U.K. Engineering and Physical Sciences Research Council. Risk Analysis, 30 (11), 1899-1707. https://doi.org/10.1111/j.15396924.2010.01517.x.

Parry, G., and Tasker, P. (2014). Value and Servitization: Creating Complex Deployed Responsive Services. Strategic Change, 23, 303-315. https://doi.org/10.1002/jsc.1978.

Porter, A., and Youtie, J. (2009). How Interdisciplinary is Nanotechnology? Journal of Nanoparticle Research, 11, 1023-1041. https://doi.org/10.1007/s11051-009-9607-0.

Savolainen, K., Backman, U., Brouwer, D., Fadeel, B., Fernandes, T., Kuhlbusch, T., Landsiedel, R., Lynch, I., and Pylkkänen, L. (2013). Nanosafety in Europe 2015-2025: Towards Safe and Sustainable Nanomaterials and Nanotechnology Innovations. Helsinky: Finnish Institute of Occupational Health. ISBN: 978-952-261-311.

Sawhney, A., Condon, B., Singh, K., Li, G., and Hui, D. (2008). Modern Applications of Nanotechnology in Textiles. Textile Research Journal, 78, 731 - 739. https://doi.org/10.1177/0040517508091066.

Stegmaier, T., Dauner, M., Von Arnim, V., Scherrieble, A., Dinkelmann, A., and Planck, H. (2007) Nanotechnologies for coating and structuring of textiles. Included in Brown, P.J. y Stevens, K (2007). Nanofibers and Nanotechnology in Textiles. London: Woodhead Publishing Limited, pp. 408 - 427. ISBN 978-1-84569-105-9.

Thompke, S., and Von Hippel, E. (2002). Customers as Innovators. A New Way to Create Value. Harvard Business Review, April.

Vila Seoane, M. F. (2011). Nanotecnología: Su desarrollo en Argentina, sus características y tendencias a nivel mundial. Master thesis. Buenos Aires: Universidad Nacional General Sarmiento. Available in: https://www.ungs.edu. ar/wp-content/uploads/2012/03/Vila-Seoane-Maximiliano-Facundo-T\%C3\%A9sis-de-Maestr\%C3\%ADa-Versi\%C3\%B3n-Final.pdf . Access on June 13 of 2016.

Von Hippel, E. (1987). Cooperation between Rivals: Informal Know-how Trading. Research Policy, 16, $291-302$. https://doi.org/10.1016/0048-7333(87)90015-1.

Von Hippel, E. (1988). The Sources of Innovation. Nueva York: Oxford University Press. ISBN: 0-19-504085-6. 